NEHAYA AWIDA HAJ-YEHYA

Higher Studies Israel

\title{
THE EDUCATIONAL SYSTEM OF THE PALESTINIAN MINORITY IN ISRAEL 'UNDER OCCUPATION': EDUCATIONAL AUTONOMY AS A RIGHT FOR MINORITIES
}

\begin{abstract}
Haj-Yehya Nehaya Awida, The Educational System of the Palestinian Minority in Israel 'under Occupation': Educational Autonomy as a Right for Minorities [System edukacyjny palestyńskich mniejszości w Izraelu "pod okupacją": edukacyjna autonomia jako prawo dla mniejszości]. Studia Edukacyjne nr 42, 2016, Poznań 2016, pp. 487-515. Adam Mickiewicz University Press. ISSN 1233-6688. DOI: $10.14746 /$ se.2016.42.28

One of the foundation stones of a democratic state is the granting minorities an autonomous educational system, so as to assure that the hegemonic group does not take over the learning contents that are important to the formation of a cultural-religious-national identity that meets the needs of these minority groups. This research study will examine the case of the Palestinian minority who are citizens of the democratic State of Israel and will attempt to examine the extent to which this right to an autonomous educational system is granted. Who decides the goals and contents of learning of the 'Arab educational system' in Israel? The research study will examine the degree of desire and realization of these unique needs. It was found in this research study that the Arab educational system in Israel is still controlled by the Jewish majority and the educational policy is determined from topdown, as expressed in the goals and contents of the studies.
\end{abstract}

Key words: Israel, educational system, Palestinian minority, autonomy

\section{Introduction}

This research study will examine the importance of educational autonomy for the Palestinian minority in Israel, especially given the background in which the special needs of students who belong to the religious-ethnicnational minority in a democratic country with a dominant group are ig- 
nored. The importance of this research study derives from the fact, as seen by the review of the literature on the Palestinian educational system in Israel, that there is tight control 'from top down' over the learning contents and learning goals in both formal and informal education, as well as ignoring of this population's needs. This institutional attitude on the part of the State of the Palestinian minority students' needs contradicts the right of the Palestinian minority to receive 'minority rights' in a democratic state. The 'flaw' of the Palestinian educational system in Israel can lead to harm to the Arab student's civic-personal and national identity, which may cause students to search for knowledge and information from sources outside of the formal framework, which is the school. This difficult situation will lead to the lack of mastery of the sources of knowledge and information for which the students will search as an alternative to the official school, since this can cause the Arab student's lack of identification with the State where he lives. Since the State ignores him, he will 'ignore' the State.

This research study will focus on the truth of the definition of the State of Israel as a democratic and pluralistic state towards the educational system of the Palestinian minority citizens of the State. This research study will attempt to examine the degree to which minority rights are granted in State of Israel, which is a signatory to the international conventions on minority rights, especially the right of educational autonomy.

This research study will endeavor to reveal the policy of the State of Israel towards the Palestinian citizens, both in economic-social terms and especially in educational terms. We will focus on the factor determining the goals of education and the contents of the study of the Palestinian educational system in Israel. Our argument is that it is very important to provide suitable education, from perspectives of values and national and civic identity for the student who will be a citizen of the State of Israel.

The importance of the present research study derives from the concern of Palestinian intellectuals in Israel about the deterioration of the situation of the educational system and more alarmingly about the situation of a 'crisis of identity' among the Palestinian student citizens of the State of Israel. Additional importance of the research study is the recommendation to the establishment to handle the problem of the Arab student's identity crisis, if it exists. If the State does not address this problem, then it will lead to instability in the security situation of the State of Israel following the alienation and feelings of these citizens that they do not belong and are "second class citizens", emotions that lessen the loyalty of the Palestinian citizens to the State in which he lives. Furthermore, the present research study will attempt to examine whether there have been changes over the years, for better or for worse, in the Arab educational system of the State of Israel. 


\section{The State of Israel - Background}

The State of Israel is a Jewish ${ }^{1}$ state in the sense that most of the citizens are Jewish (people), it serves as the nation state of the Jews (nation), and has a Jewish religious affiliation, which is expressed in the assimilation of parts of Jewish religious law into the state law. ${ }^{2}$ The establishment of the Jewish State was supposed, it would seem, to clarify the question of the Jewish national identity. The concentration of a dispersed group in one place, the assignment of full political responsibility to its shoulders, and the creation of cultural hegemony in the public sphere were supposed to serve as foundational materials for the construction of the Jewish nation. ${ }^{3}$

In Israel, a distinction and a separation exist in many areas between citizens according to their national and cultural origin, including in the field of the engagement. In addition, in the State of Israel, which is defined as a multinational country, there is a situation in which the national affiliation is not uniform for all the national groups who live therein, and the same groups develop different patriotic connections. The citizenship in Israel is presented as joint and uniform for all the citizens, but it is possible to see from the professional literature that the universalism and uniformity are but outside camouflage for hierarchical cultural patterns and perceptions built into the citizenship itself. ${ }^{4}$

The values of the existence of the State of Israel were based primarily on the Zionist, democratic, or socialist values. ${ }^{5}$ However, in the definition of the Jewish identity there is a duality of identities: civic identity and nationalethnic identity. This dual identity includes lack of clarity and conflicts derive from it. In contrast, in democratic countries the citizenship and nationality generally are identical: a Frenchman in citizenship and in nationality is a person who bears a French identity card. ${ }^{6}$

${ }^{1}$ Israel Ministry of Foreign Affairs, "Declaration of Establishment of State of Israel”, Israel Ministry of Foreign Affairs Website, 14 May 1948, Retrieved 8 April 2012; M. Brenner, S. Frisch, Zionism: A Brief History, Markus Wiener Publishers, 2003, p. 184.

Israel Ministry of Foreign Affairs, “Zionist Leaders: David Ben-Gurion 1886-1973", Israel Ministry of Foreign Affairs Website, Retrieved 13 July 2011.

2 Zilbersheid, 2009.

${ }^{3}$ Y. Stern, Proposal of a Basic Law: Trampling of Minorities, Haaretz, 2012 April, 22.

4 A. Jamal, Liberal Zionism: Judgmental Enlightenment and the Challenge of Multiculturalism in Israel, State and Society, 2004, 4.

5 Portogez, חוברת ,ישראל :מתוך .בישראל חדש שמאל של הייחודי המקרה :חדש ישראלי שמאל תנועת פורטוגז ערי

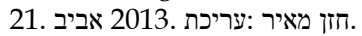

${ }^{6}$ Y. Oron, Between Jewishness and Israeliness. Relation of Jewish Students in Israel to Nation, State, Land, and Religion. Identities in Formation in Israeli Culture, The Open University, UK 2013. 
Those with an Israeli identity card are found among three national groups: Jews who are born in Israel, Jews who immigrated to Israel from other countries, and Arabs. Israeli citizenship is not identical to nationality. ${ }^{7}$ The discourse on the divisions in Israeli society reveals the state mechanisms that establish ethnic, national, religious, and gender categories. ' 'Judaism' has always been perceived as denoting a people, a nationality, and a religion. It is therefore reasonable to assume that the term 'Jewish state' is supposed to reflect the multiplicity of the facets of Judaism itself. It is necessary to read in it a cultural criterion that includes the three components together: the State of Israel is a Jewish state since it is a political-organizational framework in which main aspects of Jewish civilization in our generation are preserved and cultivated - people, nation, and religion. ${ }^{9}$

The question of the unresolved Israeli identity has weakened the shared ideological platform of Israelis. In essence, it is difficult to identify a formulation or even an attempt at a formulation of a shared ideological platform that pertains to the in-depth questions and the infrastructure of the Israeli Jewish existence. ${ }^{10}$ Therefore, it is difficult to speak about an Israeli identity or Israeli identities as one unit. The division between Israeli Arabs and Jews is most acute and steadily grows, as the Israeli-Palestinian conflict is not resolved.11 The Jewish majority preserves the situation of the Arabs as an ideological and religious national minority in the State, a significant minority in terms of size and electoral power, with low social-economic status, and a national minority related to the enemies of the State and identifying with the Palestinian people and the Arab nation and expressing its resistance to the regime and expressing their demand to receive national rights. ${ }^{12}$

Horowitz and Lisk ${ }^{13}$ maintained that Israel is a divided society and listed five divisions in Israeli society: the religious-secular division, the national division, the ethnic division, the social-economic division, and the ideological division. Their main argument is that the Israeli collective identity is shaped all the time regarding the issues at the basis of these divisions. Ac-

7 Ibidem.

8 Y. Yonah, Y. Goodman, Mix of Identities: Critical Discussion of Religiosity and Secularism in Israel, Van Lear Institute, HaKibbutz HaMeuchad Press, 2004.

${ }^{9}$ U. Zilbersheid, The Legal-Political Development of the Declaration of Independence - Victory of the Perception of Bourgeoisie Democracy, Democratic Culture, 2009, 12, 7.

10 Y. Stern, Proposal of a Basic Law: Trampling of Minorities, Haaretz, 2012 April, 22.

11 Y. Oron, Between Jewishness and Israeliness.

12 K. Abu Asba, Arab Education in Israel: Dilemmas of a National Minority, Florsheimer Institute, Jerusalem 2007; S. Smooha, Measures of Jewish-Arab Relations in Israel, Haifa 2004.

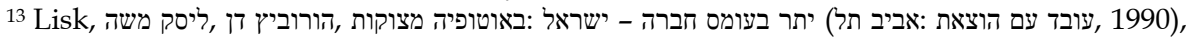
1990. 
cording to Lisk, ${ }^{14}$ in Israel there are four models of Jewish-Israeli subidentities: non-religious-secular, traditional, national religious, and Ultraorthodox religious. Alongside them and opposite them, the research presents the Israeli Arab (Palestinian) identity, which also is obviously not a single piece. ${ }^{15}$ Identity and policy of the State of Israel towards the Palestinian minority of Israel caused confusion and distortion in their identity, especially in the shadow of the struggle between integrating politically in the Zionist framework and the desire to be closed and isolate themselves through the dynamic Arab parties. ${ }^{16}$ Tzartzur ${ }^{17}$ maintained that the Arabs of Israel have a problem in their Israeli-Arab identity, since they are perceived by the Jews as a hostile minority that does not accept the existence of the State.

The values of the State of Israel as a Jewish state make it unique compared to other democratic states. There are many democratic countries in the world, but only the State of Israel is a state that is not only democratic but also Jewish. This value, "Jewish state", leads to the conclusion that the values of the State of Israel, as a Jewish state, have two main aspects: the Zionist aspect and the Halachic ${ }^{18}$ aspect or the heritage aspect. ${ }^{19}$

\section{The Palestinian Minority - Background}

The establishment of the Jewish State, in 1948, constituted for the Palestinians the Nakba (literally the disaster or the catastrophe). Many Palestinians were evicted from their homes and became refugees, and an Arab minority was created in the Jewish State. ${ }^{20}$ After the 1948 War, the Nakba, the Palestinian Arab population, which was the majority until 1948 became the minority (a minority is a group of people in the majority population, separated from the majority in national, ethnic, religious, cultural, language, and

14 Ibidem.

15 Y. Oron, Israeli Identities: Jews and Arabs opposite the Mirror and the Other, Education and Its Environment, 2010, 32.

16 S. Smooha, The Viability of Ethnic Democracy as a Mode of Conflict-Management: Comparing Israel and Northern Ireland, Comparing Jewish Societies, 1997.

17 S. Tzartzur, Arab Education: A Picture of the Situation and a Look to the Future, [in:] Jubilee for the Educational Systems in Israel, Ed. E. Peled, Jerusalem 1999, p. 1061-1085.

${ }^{18}$ Halachic refers to Halacha, the body of traditional Jewish religious law.

${ }^{19}$ A. Barak, The Values of the State of Israel as a Jewish and Democratic State, Multidisciplinary Thinking in Humanistic Education, 2011, 6.

20 A. Jamal, Struggle over Time and the Power of Temporariness: Jews and Palestinians in the Maze of History, [in:] Men in the Sun, Eds. H. Perach, T. Ben Tzi, Herzeliya: Museum, 2009. 
other characteristics). ${ }^{21}$ This minority is considered a minority in terms of nationality and language, ${ }^{22}$ in which there is an additional division according to the religious definitions - Muslims, Christians, and Druse, 23 82\% Muslims, 9\% Christians, and 9\% Druse (Saar, 2007). The Arab minority has additional uniqueness, since it has a homeland. This is a native Palestinian Arab population, which lived in its homeland - along with members of its people - even before the establishment of the State of Israel, when it was found in the majority group (Gavarin, 2010). This fact influences the struggle for the borders of the collective identity of both Jews and Arabs in Israeli society. The struggle is related not only to the fact that Israel is a country of immigrants but also to its place in the Middle East, and it emphasizes the issue of the complex relation between the Arab minority and the Jewish majority. ${ }^{24}$

Most of the Palestinians who became citizens of the new State of Israel did not lose their homes, but they also suffered greatly from the loss of lands and livelihoods and often were disconnected from their close family. Since 1948, the agricultural industry has declined, when this had been the source of livelihood of the Israeli Palestinian, following the expropriation of their lands, and thus caused a process of proletarization. However, the Israeli Palestinians continued to live in their villages, which grew into towns and cities (Zahalka, 1998). ${ }^{25}$ The Arab population that remained in the boundaries of Israel belonged to the weaker parts of the original population (many others, including political and economic leaders, left or were evicted from Israel). ${ }^{26}$

The perception of the Palestinian minority was that of a security risk that threatens the establishment of the State in the construction of the new Jewish State, whose neighbors did not recognize its existence. ${ }^{27}$ The Arab citizens of

${ }^{21}$ M. Al-Haj, The Situation of the Arab Education. Identity, Coexistence and Contents of Education, The National Committee of Chairmen of Arab Local Authorities and the Follow Up Committee for Arab Education, 1988, 1.

22 S. Smooha, Measures of Jewish-Arab Relations in Israel.

${ }^{23}$ B. Noyberger, Minorities and Democracy, [in:] Knowledge, Society, and Regime, Jerusalem 1995.

${ }^{24}$ Eisenstadt, 1989, in: A. Ghanem, M. Levin-Rosales, Game of Identities: The Construction of Identity among Palestinian Women Citizens of Israel Who Studied in Schools in the Jewish Sector, Trends, 2015 May, 51.

${ }^{25}$ R. Hamisi, Strategies of Settlement in the Occupied Territories and Implication on the Main Planning and Development in Palestine, Journal for the Research of Palestinianism, 1998 Winter, 10(37).

${ }^{26}$ B. Kimerling, Y.S. Migdal, Palestinians: A Nation in Formation, Jerusalem 1991; B. Morris, Victimization, Am Oved 2003.

${ }_{27}$ M. Amara, I. Saban, The Status of the Arabic Language in Israel: Law, Reality, and Boundaries of Use in Law to Change the Reality, State and Society, 2004, 4, p. 885-909; O. Stendel, Arabs of Israel: Between Hammer and Anvil, Academon, 1992. 
Israel lived in the years 1948-1966 as a minority in the Jewish majority, under a military government, in a state that began to form its identity and decided that it would be democratic. ${ }^{28}$ The military government over the Palestinian minority in Israel shaped the existence of the Arab sector. ${ }^{29}$ The military government was established by the force of the Emergency Defense Regulations legislated in the Land of Israel by the British Mandate government in 1945. This government was perceived as the main device through which it would be possible to have close supervision and control over the Arab minority, and it enabled the exclusion of the Israeli Arabs from the different systems of the State. ${ }^{30}$

The period of the military government extended from 1949 to 1966. In this period the Arabs lived under close supervision. Their freedom of movement and expression were restricted, they were denied the possibility of accumulating capital, and the social-economic structure remained as it was. In addition, the military government had a direct relationship with the heads of the Arab clans, tribes, and communities, while ignoring their shared national identity. Thus, the Arabs did not have the possibility of unification into a collective. ${ }^{31}$ In the period of the military government, the Palestinians in Israel had the increasing confidence and need to integrate into Israeli society, to develop their status as Israeli citizens, to find solutions to their problems, and to think about their future. ${ }^{32}$ The main goal of the Arabs of Israel was to survive. Therefore, in this period there was no real political activity among them and there was cooperation between the heads of the Arab clans and the leaders of the Jewish parties. ${ }^{33}$ Lustik $^{34}$ described the Arabs of Israel in this period as 'quiet and submissive'.

The situation of the Palestinians outside of Israel in the parallel period (1948-1960) was different. They shared the sense of humiliation following the Nakba as did their fellows, the Arabs inside Israel, and even were forced to absorb refugees in camps nearby. However, they were residents of Jordan

${ }^{28} \mathrm{H}$. Koren, The Identity as Awareness: The Palestinians and the Arab Citizens of Israel - Between Unity and Uniqueness, National Security, 2009 August, 7.

${ }^{29}$ A. Ghanem, M. Mustafa, The Palestinians in Israel - The Policy of the Minority in the Ethnic State, Medar - The Palestinian Center for the Study of Israeliness, 2009; O. Stendel, Arabs of Israel: Between Hammer and Anvil.

${ }^{30}$ Y. Boymel, Principles of the Policy of Discrimination towards the Arabs in Israel, 1948-1968, The New East, 2002.

${ }^{31}$ K.T. Sheferman, Arab Identity in a Jewish and Democratic State, Parliament: Portrait of the Israeli Public, 2008 April, 58.

32 A. Ghanem, M. Mustafa, The Palestinians in Israel - The Policy of the Minority.

$33 \mathrm{~S}$. Smooha, Arabs and Jews in Israel.

${ }^{34}$ I. Lustik, Arabs in the Jewish State: Israel's Control of a National Minority, Austin, Texas 1980. 
(West Bank) and Egypt (Gaza Strip), and they could attempt to realize their feeling of vengeance against the 'Zionist enemy' outside, without a Jewish society that forces on their internal brothers limitations, primarily the 'military government' in the years 1948-1966. In addition, the Palestinians felt the support and sympathy of their Arab brethren in the countries where they lived. ${ }^{35}$

In this situation, the Arabs inside Israel had no option but to attempt to survive in their state in an optimal manner. They understood that they must stay close to their lands and examine the meaning of their existence in a state with a Jewish majority that calls for democracy. For this purpose, they began to learn Hebrew and the culture of the Jewish majority in the Arab educational system, and in the first decades there were attempts to fit into the Israeli job market. In this way, the Arabs inside Israel believed that they would advance as individuals and as a community. The first means were in the field of education and employment. ${ }^{36}$ With the end of the military government in 1966, a change occurred in the political awareness of the Arabs of Israel (Katoryamo, 2002) ${ }^{37}$ and a new leadership began to grow among the young Arabs, who acquired their education in universities. ${ }^{38}$

The main argument of the research study is that although the government was established for security reasons that were justified at the time, over the years it penetrated into all areas of civilian life and became a political, economic, and social instrument of control over the Arab minority by the State. It is further asserted that the reason the military government continued for eighteen years was not purely security-oriented. Senior security experts recommended cancelling the military government, political parties on the right and on the left struggled to remove it, but the mechanism continued to maintain itself and was reinforced by the Prime Minister and Minister of Defense, David Ben Gurion, when he and his party used it for their political needs. 39

This argument on the increase of the level of education in the period of the British government is true, as a result of the Compulsory Education Law of 1949, which provided free and mandatory education to all children in Israel. However, the present research study considers it important to exam-

${ }^{35}$ H. Koren, The Identity as Awareness.

${ }^{36}$ Ibidem.

${ }^{37} \mathrm{M}$. Al-Haj, The Political Organization of the Arab Population in Israel, The Development of a Center in the Margins, 1992.

${ }^{38}$ Ibidem; A. Arian, P. Ben-Nun, S. Barnea, The Measure of Israeli Democracy, Adults and Youths, 2004.

${ }^{39}$ S. Ozacky-Lazar, The Military Government as a Mechanism of the Control of the Arab Citizens, 1948-1958, A New East, 2012, 43. 
ine the contents and goals of education and the quality of the 'good' education that the Palestinian citizens of the State of Israel received in the period of the military government, when the military governor had influence over the system and intervened in the goals and contents of education. It is important to examine today, in the year 2016, who decided the goals of education and the study contents of the books in the Arab educational system. Is it possible to argue that in essence the Arab educational system is still found under occupation, or what was called in the past 'military government', although the military government formally ended decades ago? Is the policy of the military government still operating implicitly - and intentionally? The present research study seeks to examine these questions.

\section{The Right to Education}

According to Rom, ${ }^{40}$ education is one of the foundation stones of every society and is inseparably related with the cultural, political, and social environment in which it is implemented. According to many researchers, the right to education goes hand in hand with social justice and constitutes a significant component on the way to the closing of gaps and the promotion of society ${ }^{41}$ since the right to equal education is vital to the promotion of the principle of equality of opportunities. ${ }^{42}$ Dahan maintained that for the most part social and economic gaps are translated into the classroom, and therefore a just educational reality depends on a just social and economic reality. The educational system is supposed to reduce and even eliminate the social inequality that exists in the State and to reduce the gaps between the different groups that comprise it. 43

Hence, the right to freedom by its very nature obligates the existence of the right to education, disconnected from the scope of the appropriate intervention of the State in the 'private sphere'. Moreover, the duties of the country to education do not end with the accessibility of the population to educa-

40 A. Rom, The Process of the Development of Curricula in Five Chosen Countries, Jerusalem 2009.

${ }^{41}$ I. Abu Shindi, Educational Coping with the Arab-Jewish and Social-Economic Schism, Multidisciplinary Thoughts in Humanistic Education, 2010, 5, p. 75-76; Y. Dahan, Companionship? Depends for Whom? The Sting, 2010 November 16, Retrieved on April 30, 2012 from: www.haokets.org/2010/11/16 שקל-אלף-35-תמורת-מנהיג; D. Lautman, Education as the True Way to Close Gaps and Promote Society, Multidisciplinary Thought in Humanistic Education, 2009, 4.

${ }^{42}$ Y. Dahan, Companionship? Depends for Whom?.

${ }^{43} \mathrm{~K}$. Abu Asba, The School Principal is Subject to Great Pressures on the Part of the Clans, Another Country 2004. 
tion, but rather there is commitment to encourage the individual's participation in the educational system and in the shaping of the right to learning in the spirit of the right to freedom. ${ }^{44}$ Education is also perceived as a tool for the accumulation of political power. Zisnavin ${ }^{45}$ argued that there is a close relationship between politics and education.

A democratic society sees public education to be a bridge that helps lead the young generation to their lives as citizens in a democratic country. This type of education, which is included in the areas of responsibility of the State, will facilitate the normal functioning of democracy and will preserve its existence for many years. ${ }^{46}$

According to the model of Tomasevski, ${ }^{47}$ education is a real right only when it is available, accessible, acceptable, and adjusted. In his opinion, acceptable education is education that satisfies the students' parents in terms of its quality and in terms of the relevance of the learning contents and the values conveyed to their children. For education to be acceptable, the State must avoid political or religious indoctrination and cultivate open education that is forgiving towards different voices and competing narratives. Adjusted education is education in which there is adjustment to the needs that change from group to group in society and to the students' local context, language, and culture. Simultaneously, the State must ensure that the contents and messages of education are available and accessible to the students in an equal manner, without any discrimination. ${ }^{48}$

As aforementioned, the educational system and the schools in essence serve as a main instrument for the training of the future citizens of the democratic state. This training makes the national unit sovereign over the educational citizenship process of its future graduates. The structure, contents, national environment and organization of the studies of the system are one unit, focusing on education for citizenship in a democratic regime. ${ }^{49}$

${ }^{44} \mathrm{H}$. Kalai, The End of the Race is Determined by the Beginning Thought, Journal of the Law Bar in Israel, 2014, 23, p. 116-121.

${ }^{45}$ D. Zisnavin, The Jewish Educational System in Israel from the Days of the Initial Settlement until Today, [in:] Changes in Education, Eds. Dror, Nevo, Shapira, UK 2011.

${ }^{46}$ O. Ichilov, Establishment of Public Education in Israel and Retreat from It, [in:] Privatization and Commerce in Public Education in Israel, Ed. O. Ichilov, Ramot, Tel Aviv 2010, p. 21-50.

${ }^{47} \mathrm{~K}$. Tomasevski, Globalizing What: Education as a Human Right or as a Traded Service? Indiana Journal of Global Legal Studies, 2004, 12(1), p. 1-78.

48 Ibidem.

${ }^{49}$ G. Talshir, Citizenship, Civil Society, and Education: The Israeli Case in the Mirror of Western Democracies, [in:] The Language of the Citizen in Israel, Eds. G. Talshir, D. Anon, Jerusalem 2006. 


\section{The Sectors in the Israeli Educational System}

In the year 1953 the Israel Knesset (Parliament) passed the State Education Law, The law details the following objectives for education in Israel: to establish the education on the values of Jewish culture and the achievements of science, on the love of the homeland and loyalty to the State and to the Jewish people, on work in agriculture and in craft, on trust, and on the struggle to create a society based on freedom, equality, tolerance, mutual assistance, and love of humankind. 50

The character of the state education sector was influenced largely by Western perceptions, from the perception according to which it is necessary to adhere to Western culture, which inculcated the values of enlightenment and education that characterize the modern era (education for aesthetics, education for art and music, and physical education). While state education included the focus on the Zionist and Jewish doctrine, Western general education was accorded greater weight than that of Zionist and Jewish education. The emphasis placed on the Western values was so prominent that it as possible to call this perception 'Eurocentric'. ${ }^{51}$

The State Education Law, with the changes that occurred in it, arranges the structure of state education in Israel into two main sectors: state education and state religious education. The state religious education sector incorporates Jewish religious values, which were an inseparable part of the historical identity of the people of Israel. ${ }^{52}$

The law anchors the status of another sector as a sector that is not a state sector: the independent education sector. This sector acts primarily in education institutions that belong to the Ultra-Orthodox sector. ${ }^{53}$ The recognition of Ultra-Orthodox education as an independent sector gives it the right to enjoy the budgets of the State at an increased rate without its institutions being obligated to the learning contents determined by the State. Although the law determines that the Minister of Education has the authority to obligate for these institutions $75 \%$ of their curriculum, this does not happen in actuality and the contents learned in these institutions are not influenced by outside factors. The attempts of the Ministry of Education to change the

${ }^{50}$ S. Mari, Arab Education in Israel, Syracuse - New York - Boulder 1978.

51 Shenhar Committee Report, 2012.

52 Z. Gross, State Religious Education in Israel: Between Tradition and Modernity, [in:] Education as a Social Challenge, Eds. Z. Gross, Y. Dror, Tel Aviv 2004.

53 E. Feldman, Ethnicity, Politics, and Education - The First Decade of Independent Education, 1953-1963, From Generation to Generation, 2007, 31, p. 1301-1334. 
situation have failed since the political ranks (the Ultra-Orthodox parties, with Shas Party at their head) have refused to cooperate. ${ }^{54}$

The Arab educational system, which had existed before the establishment of the State of Israel as a separate system for the majority of the Palestinian Arabs, was made subordinate after the establishment of the State to the Ministry of Education and in essence became an inseparable part of state education in the country. ${ }^{55}$ Therefore, in Israel there is a division into a Jewish educational system and an Arab educational system. ${ }^{56}$ As aforementioned, the State Education Law emphasizes the cultivation of the Jewish identity and values but does not determine any parallel objectives in Arab education in Israel, although there were attempts in the 1970s-1980s to do so in committees headed by Jewish educators. ${ }^{57}$

\section{The Core Studies in the Israeli Educational System}

According to Piron, ${ }^{58}$ the core studies are supposed to meet two main needs: learning of the basic nature of the country and determination of the contents that should be inculcated in the children. In other words, what is the educational product we seek to establish in the $21^{\text {st }}$ century? The idea at the center of the core program is the establishment of a shared basis for a multicultural society and creation of social solidarity. However, in the political reality in Israel it serves for the exclusion of Arabs and UltraOrthodox, groups that threaten the hegemony of the dominant class. ${ }^{59}$

Until today, full agreement among educators and in the Ministry of Education on the topic of the nature of the core program has not been formed. ${ }^{60}$

${ }^{54}$ I. Abu-Saad, Multicultural Education and the Palestinian Arab Minority in Israel: The Issue of Bedouin Arab Education in the Negev, [in:] Education in a Multicultural Society: Pluralism and Points of Encounter between Social Rifts, Ed. P. Pery, Jerusalem 2007, p. 125-142.

55 Y. Jabareen, A. Agbaria, Autonomy for Arab Education in Israel. Rights and Possibilities, Knowledge Discovery, 2014 Spring, 5.

${ }^{56} \mathrm{M}$. Al-Haj, Education, Empowerment, and Control: The Case of the Arabs in Israel, Albany New York 1995; S. Mari, Arab Education in Israel.

${ }^{57}$ M. Al-Haj, Kinship and Modernization in Developing Societies: The Emergence of Instrumentalized Kinships, Journal of Comparative Family Studies, 1995 October, 26(3), p. 311-328.

58 S. Piron, Educational Core: On the Importance of the Cultural Individual, Personal Development, and the Scholastic Level, Multidisciplinary Thinking in Humanistic Education, 2011, 6, p. 39-41.

${ }^{59}$ Markman, Yonah, Markman, Yonah, 2010

אל...... אלפיים .להדרה הכלה בין :בישראל חינוכית וליבה תרבותיות-רב , לאומיות ,2009 .י,ויונה .נ מרקמן

${ }^{60}$ S. Bargouti, Israeli Educational Core Requires Fair Inclusion of the Arab Public, Multidisciplinary Thought in Humanistic Education, 2011, 6, p. 42-44. 
Piron 61 described a number of different approaches regarding the core programs. According to one approach, core studies are important to the individual student, so as to convey to him the knowledge, the tools, and the opportunities required for personal growth and self-fulfillment. A second approach maintains that core studies are necessary for society, as an anchor of the assets of the culture as well as its objectives and goals. According to the third approach, the core studies are essential so as to create a basic common denominator in all the frameworks of education, which will allow the creation of a national educational infrastructure. Such an infrastructure can facilitate the reduction of the scholastic and social gaps and ensure the quality of the educational system.

The core program is composed of a collection of select contents, when it was decided that these would allow the school to achieve the objectives determined by the Ministry of Education. ${ }^{62}$ The basic goals of the core program are to maintain the social stability and to preserve the cultural uniqueness that characterizes the groups in the country. ${ }^{63}$

The objectives of value-based education in Israel discuss the need to instill in the student the values of the State of Israel as a Jewish state, without reference to the fact that in this society there is an Arab minority, with its own nationality, and its right is to be an integral part of this society. ${ }^{64}$ The Jewish schools greatly emphasize the development of the national identity, the active affiliation with the Jewish people, and the promotion of the Zionist aspirations - and all these while granting the most minimal recognition to Arab history. Bar-Tal ${ }^{65}$ studied the textbooks in the elementary schools and middle schools and found that the Jewish textbooks (grammar, Hebrew language, history, geography, and civics) present a uniform position - the Jews are involved in the just and even humane war against the Arab enemy, which refuses to recognize the existence and rights of the Jews in Israel and to accept them. Where the curriculum mentions the Arabs, for the most part it tends to present them and their culture in a negative light. More than a few research studies have been conducted on textbooks intended for Jews in Israel and Israeli children's literature, and they discovered that the Palestinians and Arabs are presented in many cases as 'murderers', 'rioters', and

${ }^{61}$ S. Piron, Educational Core: On the Importance of the Cultural Individual, Personal Development.

${ }^{62}$ Y. Katz (Ed.), Towards an Educational Revolution, Following the Van Lear Conference for Education on the Implementation of the Dovrat, Report, 2006.

${ }^{63}$ N. Rottenberg, Shared Educational Core for the Children of Israel: Obstacles and Overcoming Them, [in:] Towards an Educational Revolution, Ed. D. Inbar, Van Lear Institute, 2006, p. 214-227.

${ }^{64} \mathrm{~S}$. Bargouti, Israeli Educational Core Requires Fair Inclusion.

${ }^{65}$ Bar-Tal 1998, in: I. Abu-Saad, Multicultural Education and the Palestinian Arab Minority in Israel. 
'suspects' and in any event as weak and not productive. 66 Requests to formulate goals that recognize the Arab minority in the Jewish democratic state submitted by Arab intellectuals have always been rejected. ${ }^{67}$

Therefore, in the present situation of the educational system in Israel, it is impossible to crystallize a core program shared by Arabs and Jews. The educational discourse in Israel, official and public, is based on the principle to cultivate educational values based on the values of the State of Israel as a Jewish and democratic state. 68

Markman and Yonah ${ }^{69}$ maintained that at the basis of the 'core idea' there is the recognition of the multiculturalism that characterizes society and the need of these cultures to maintain their identity and heritage. However, the engagement in the topic of the core, as reflected in the public and political arenas in Israel, is guided by a different logic. This idea serves as a means for the coping with the threat that multiculturalism supposedly presents to the nation state and as a means of preserving the supremacy of a collective that excludes many social groups.

Therefore, it is possible to form a shared core for the different Jewish sectors - secular, religious, and Ultra-Orthodox - since they form around shared values. The issue is that this type of program does not include the Arab citizens. Hence, as long as the educational discourse discusses the State of Israel as a Jewish state and the contents and objectives of the educational system are thus determined, the Arab public will find it difficult to fit into the general core program. ${ }^{70}$

\section{Arab Education and the Educational Rights of Palestinian Minority in Israel The Position of the State of Israel on Giving Educational Rights to Its Palestinian Minority}

It is the right of a national minority to enjoy the state educational system in its language. In Israel, there indeed is a system of elementary and high schools in Arabic for the Arabs of Israel. ${ }^{71}$

${ }^{66}$ Ibidem; Meehan, 1999, in: ibidem.

${ }^{67}$ S. Bargouti, Israeli Educational Core Requires Fair Inclusion of the Arab Public.

68 Ibidem.

הכלה בין :בישראל חינוכית וליבה תרבותיות-רב, לאומיות , 2009 .י,ויונה .נ מרקמן 2010 Markman, Yonah, אלפיים .להדרה

${ }^{70}$ S. Bargouti, Israeli Educational Core Requires Fair Inclusion of the Arab Public.

${ }^{71}$ B. Noyberger, Minorities and Democracy, [in:] Knowledge, Society, and Regime. 
According to this school, another fundamental right of a native minority is the right to influence the educational contents. Hence, the Palestinian minority in Israel has the right to educational autonomy, since the right to influence the education contents is a right in principle because of the culture and degree of cultural freedom that the minority group enjoys in the choice of its identities and in the determination of the values according to which it wants to live and educate the future generations. ${ }^{72}$

The State of Israel respects the right of the Arab population to have an educational system in Arabic, but the right to education in the mother tongue does not fulfill the rights of minorities in the field of education, such as the right to have cultural-educational autonomy, so as to maintain the cultural-natural heritage and identity, to shape it, and to develop it. ${ }^{73} \mathrm{Al}-$ though the State Education Law (1953) defines the state educational system in Israel as well as the objectives of the system, it does so only in Jewish terms and for Jewish students. The collective educational interests of the Palestinian-Arab citizens in Israel are almost completely ignored in the language of the law. ${ }^{74}$

Saban (2002) connected between the group rights given to the minority group, so that it can protect its cultural difference and express its uniqueness in actuality, and the ability of this group to influence in the framework of the democratic process on the course of its public life in the State. In this context, it is possible to note that, according to Foucault (1918), every educational system is a political instrument for the preservation or shaping of the discourse on the knowledge and power relations that it bears.

In the year 1949, the Compulsory Education Law was passed, with the goal of ensuring a basic education for all citizens of Israel, including the Arab citizens. ${ }^{75}$ Following the law and the deployment of the military government, there was a blurring of the rights between the Ministry of Education and the system of the military government under which the Arabs of Israel were subordinate until 1966. The military government intervened in many areas and sometimes even intervened in the field of the Ministry of Education. ${ }^{76}$ It is necessary to keep in mind that Arab education in Israel acts in the context of a country with a Jewish majority. This fact leaves the con-

72 A.K. Agbaria, Y. Jabareen, Policy of Training Arab Teachers in Israel in the Mirror of the Right to Education: Issues of Governance as an Expression of Recognition of the National-Cultural Uniqueness, Journal for Study and Research in Education, 2015.

${ }^{73}$ Y. Rabin, The Right to Education, Nebo 2002.

74 Y. Jabareen, Law and Education: Critical Perspectives on Arab Education in Israel, American Behavioral Scientist, 2006, 49(8), p. 1502-1574.

${ }^{75}$ Y. Dror, Interconnected Vessels in National Education: The Zionist Story, Jerusalem 2007.

${ }^{76}$ M. Al-Haj, Kinship and Modernization in Developing Societies. 
trol in the hands of the majority group, while the minority group has limited involvement in its contents. ${ }^{77}$

All schools in Arab society in Israel act under the supervision and with the financing of the Ministry of Education, and they are affiliated to some degree or another with the state education sector. This affiliation is expressed today primarily through the guidance and management staffs in the districts, the general and professional supervisors of the Ministry of Education, and the small and unique headquarters units in the internal subdivision that exists today as subsectors in Arab education. ${ }^{78}$

Israeli legislation has yet to recognize explicitly the right of the Arab minority to influence education, not as a private right but as a group right, despite the trend in the legal discourse to adjust the educational system to the multicultural reality in Israel. Lacking any legal and content-oriented arrangement engaging in Arab education, the law gives nearly absolute governmental freedom of action to the Ministry of Education, and it controls the Arab educational system in a significantly centralized manner, both on the school level and on the level of the colleges of teacher training. ${ }^{79}$

The policy of the Ministry of Education in Israel in essence neutralized the influence of the Arab public on the education of its children and swept the Arab students into the general state education system. In the Ministry of Education a special department for the Arab educational system was established, when this department was subject to the directives of the Ministry, without any autonomy, and until the year 1989 the department head was a Jewish manager. ${ }^{80}$ The last remnant actually remaining the hands of the Arab public from the self-management of education is the Arabic language. ${ }^{81}$

The Dovrat Committee was established in the year 2003, with the goal to conduct a comprehensive examination of the educational system in the State of Israel and to recommend a comprehensive program of change - pedagogical, structural, and organizational - and the formation of a way for the implementation. ${ }^{82}$ It proposed the educational reforms connected with achievement and testing. The report of the committee expressed conflicting voices, especially in the context of Arab education. On the one hand, the

77 K. Abu Asba, Arab Education in Israel: Dilemmas of a National Minority.

78 Ibidem.

${ }^{79}$ A.K. Agbaria, Y. Jabareen, Policy of Training Arab Teachers in Israel in the Mirror of the Right to Education.

${ }^{80}$ I. Saban, The Collective Rights of the Palestinian Arab Minority: What There Is, What There Isn't, and the Taboo, Studies in Law, 2002, 26, 1, p. 241-319.

${ }^{81}$ K. Abu Asba, Arab Education in Israel: Dilemmas of a National Minority.

82 Dovrat Report, 2005. 
report acknowledged legally the existence of the separate channels of education, in terms of the existence of separate nation and language and lifestyle, and the need to give, despite the conflict, an expression also to the separate Arab heritage and the full loyalty to the State of Israel. However, because of the deep concern about the split of the Arab educational system from public education, which may lead to the loss of a feeling of partnership in Israeli society, the report negated the right of Arab and Druse education to autonomy and independent educational management with self and collective control on the schools. Therefore, instead of an autonomous educational manager for Arabs, the Israeli educational establishment remained subjected to the purpose of the integration in the State of Israel as a Jewish and democratic state. ${ }^{83}$

According to the reports of the Dovrat Committee, it is necessary to develop the goals of Arab education so as to develop and cultivate the personal identity and the group Arab identity as an emotional and social educational anchor for full integration in Israeli society and in the State of Israel as a Jewish and democratic state and to recognize Jewish culture, language, and history. This duality of the report expresses the recognition of the collective identity of the Arab minority and the demand that Arab education be committed to the goals of public education. ${ }^{84}$

In the year 2005 the Dovrat Committee submitted the final committee report, in which it suggested the Public Education Law, the goal of which is to cope with the problems in the existing laws of education, such as discrimination on the background of class or budget between the state institutions and the Ultra-Orthodox education institutions. These enjoy the budget that the State grants them but they are not supervised or are minimally supervised. The Report further noted that the split that characterizes Israeli society leads to a feeling of lack of partnership in it and that the demographic increase in the Arab and Ultra-Orthodox sectors further this schism. The report emphasized the value-oriented realm and notes the very important role of education as the basis of the culture and ethnic unity. It was further noted that education is a condition of integration in society and in the public life in a democratic state. Education, according to this report, must inculcate the universal and national values that society aspires to inculcate. Success is when it creates citizens with a shared language and social solidarity, with values of consideration of others, contribution to society, equality,

${ }^{83}$ A.K. Agbaria, I. Mahjana, Arab Education in Israel, between the Discourse of Achievement and the Discourse of Recognition, Two Thousand: Multidisciplinary Journal for Review, Philosophy, and Literature, 2009, 34, p. 111-129.

${ }^{84}$ Ibidem. 
and justness, and concurrently the different sources of cultures at the basis of society will be preserved and developed. According to the Committee Report, the success of the State in the field of education will largely determine its future. 85

\section{Teacher Training in the Arab Educational Sector: Institutions for Training Arab Teachers}

The teacher has a main role, both as a teacher and as an educator, in the cultivation of the student's personality and in the concern for his wellbeing. ${ }^{86}$ Therefore, the State's control of the training institutions for teachers is a part of the broader phenomenon of the State's control of education, including control of the structure, financing, contents, and teachers' work. The purpose is to achieve governmental stability, shared political identity, economic growth, and so on. ${ }^{87}$

The training of the Arab teachers, as in any other educational process, may shape and educate the teachers for the choice of contents, the emphasis placed in the program on the different areas of knowledge, the resultant values, the degree of critical orientation, and the way in which the lesson are conveyed. In addition, the training of the teachers is also expressed in the education for social awareness, professional skills, and correct perception of the teacher of his role in society. 88

According to Mahajana, ${ }^{89}$ the training of the teachers is specific and limited in scope and its goal is to adjust the training of the Arab teacher to the uniqueness of Arab society, with its systems and institutions. There is minimal and negligible unique training of the Arab institution, whose purpose is to increase the awareness and to create commitment in the teachers of the future for the establishment of a just society through reference to sociocultural aspects of the Arab students. The didactic policy that ignores the indi-

${ }^{85}$ National Task Force for the Advancement of Education in Israel, 2005, p. 50.

${ }^{86}$ I. Gilat, To Be Close: First Aid for the Teacher in Coping with the Students' Troubles, Tel Aviv 2007.

87 J. Zadja, H. Daun, L.J. Saha (Eds.), Nation-Building, Identity and Citizenship Education, Cross Cultural Perspectives, 2009.

88 I. Zimran, There Is Another Way - Self-Education of Teachers for Meaningful and ValueOriented Teaching, [in:] Values and Education for Values: Issues in Teacher In-service Training, Ed. M. Bar-Lev, Jerusalem 1999.

${ }^{89}$ I. Mahajana, The Declared Policy in the Training of the Arab Teachers in Israel to Cope with Students in Distress and in Crisis, [in:] The Training of Teachers in Palestinian Society in Israel, Ed. A. Agbaria, Ressling 2013. 
vidual's distress is commensurate with the assertion of Jabareen and Agbaria ${ }^{90}$ that the training of Arab student teachers does not acknowledge the uniqueness of Arab society as a native minority that is discriminated against and exposed to an official institutional policy with the purpose of cementing its inferiority, dependence, and marginality, with all the implications of this policy.

Hence, the educational system and in it the institutions for teacher training had a central channel in the cooptation of the Arab academics, while making them into public workers who perceive their role as that of an official. In other words, the institutions of teacher training have a main role not only in the reconstruction and replication of the ideology of the control of the Arab society in Israel but also in the inculcation and instilment of the skills and values required for its internalization as normal and desirable. Simultaneously with the dissemination of the Israeli story and the institutionalization of the hierarchy between Jews and Arabs and in the Arab population itself, the institutions of teacher training had a main role in the camouflage of the repression and control through the covering of them with an image of professionalism. The purpose of this image was to shape the role of the teacher as an apolitical and asocial function, in the sense that the role of the Arab teacher was devoid of initiative and creativity and there was no requirement to be critical, capable or socially and civically involved. ${ }^{91}$

\section{Appointments and Layoffs of Arab Teachers in the Palestinian Educational System in Israel}

The role of the teacher and educator is expressed in the cultivation of the student's personality and in concern for his wellbeing. ${ }^{92}$ Therefore, the recruitment of the teaching force in the Arab educational system was determined also according to political considerations. The empowerment of teachers, principals, and supervisors is given to the Ministry of Education, and the meaning is that to be an Arab teacher in the Arab educational system it is not enough to have training and teaching certificates. Rather, it is

${ }^{90}$ Y. Jabareen, A.K. Agbaria, Education on Hold; Government Policy and Civil Initiatives for the Promotion of Arab Education in Israel, Haifa 2010.

91 A.K. Agbaria, Arab Civil Society and Education in Israel: The Arab Pedagogical Council as a Contentious Performance to Achieve National Recognition, Race, Ethnicity, and Education, 2013, p. 1-21; Introduction: The Policy of Training of Arab Teachers in Israel - The Demand for National and Pedagogical Uniqueness, [in:] Training Teachers in Palestinian Society in Israel - Institutional Practices and Educational Policy, Ed. A.K. Agbaria, Resling 2013.

92 I. Gilat, To Be Close: First Aid for the Teacher in Coping with the Students' Troubles. 
necessary to have a security clearance - without the teachers' knowledge and to receive the confidential approval of the Israel Security Agency (Shabak). 93

The governmental control of the Arab educational system was also expressed strongly in the appointment of teachers, principals, and role-holders in the Arab schools. The appointment of the teachers and the principals is subject to the approval of the Israel Security Agency. ${ }^{94}$

The Palestinian teacher in Israel was transformed from politically involved to an apolitical technocrat. ${ }^{95}$ The role patterns of the Arab teacher in Israel changed according to the historical circumstances and the ability of the training institutions to shape the learners in them. ${ }^{96}$ Many of the Arab teachers feel that they must deal with value-oriented and professional dilemma: on the one hand, they are expected to teach and to strengthen the Palestinian Arab identity but on the other hand, they are supposed to teach according to the Israeli curriculum that does not include in it the Palestinian issue (Elian, 2013).

Conversely, Mazoy described the expectations of Arab society of the Arab teacher, who is a part of it and who works in it, to contribute to the shaping of the Palestinian students' awareness and collective identity and to help them achieve social mobility in Israel.

\section{Determination of the Educational Goals of the Arab Educational System by the Establishment}

The State Education Law sets as main goals, on the one hand, the equality of opportunities for every boy and girl, to allow them to develop according to their path, and to create an atmosphere that encourages difference and supports it. On the other hand, the law itself creates discrimination and harms the equality of opportunities for the Arab children, and this is the recognition of the Palestinian Arab identity. In addition, the law further fo-

${ }^{93}$ M. Al-Haj, Higher Education among the Arabs in Israel: Situation, Problems, and Trends, Haifa University, Haifa 2001.

${ }^{94}$ R. Gabizon, N. Balfour, Between Demand for Liberty and Autonomy of Arab Education in Israel: Rights and Possibilities, 2005.

95 Mazoy. a et al., מעמד :בישראל הערבי המורה , הוצאת ... החינוך לחקר המרכז :חיפה .וציפיות שאלות

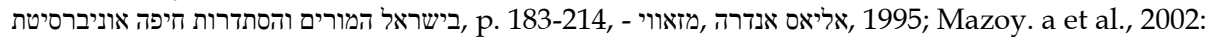

. :בתוך ,"בחינוך הפמיניסטי המחקר :מבוא" ... - ... 27-952 פורמאלי והברלתי הפריה הפורמאלי בחינוך מגדריים היבטים

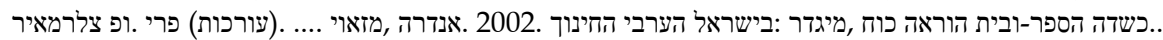

${ }_{96}$ A.K. Agbaria, Arab Civil Society and Education in Israel; A.K. Agbaria, Introduction: The Policy of Training of Arab Teachers in Israel 
cuses the definition of the State as 'Jewish and democratic', a definition that excludes the Arab population and discriminates against it both on the level of principle and the level of practice. ${ }^{77}$

In essence, the Arab educational system is not defined in any section in the law, and hence the Arab educational system is devoid of the conceptual and content existence in the Book of Laws. From this perspective, it is possible to learn that Arab education is a matter of present-absent in Israeli law. ${ }^{98}$

The goals of Arab education, from the year 1953 to the year 2000, have not undergone any essential change. The formulation of the goals completely ignored the Arab students. Hence, it is clear that the goals of education serve the majority group and were intended to promote exclusively the Jewish national agenda. ${ }^{99}$ While the focus of the Jewish educational system is Zionist and national, the Arab educational system lacks any Palestinian Arab content. The Arab educational system attempts to strengthen the cultural-religious component instead of the Arab-national component, since the perception is that the Israeli Arabs constitute a potential security risk for instability. 100

Al-Haj 101 indicated three different approaches faced by the decision makers when they go to crystallize the structure of the relations between Arabs and Jews in the educational system: assimilation, separation, and integration.

The overall control of the Jewish educational system over the Arab educational system prevents the Arab population any possibility of determining its educational objectives, deprives its right to shape and direct the educational system according to its collective interests, and frustrates every significant involvement of Palestinian-Arab educators in the process of decision making, with regard to both the budgets and the contents of education intended for the Arab students. ${ }^{102}$

${ }^{97}$ D. Avnon, The Non-Democratic Aspect of the Basic Laws on the Topics of the Rights of Man, Politics, 1998, 2, p. 53-70; Y. Jabareen, On the Constitutional Status of the Arab Minority in Israel: New Motion, State and Society, 2010, 7(1), p. 105-139.

${ }^{98}$ Y. Jabareen, A.K. Agbaria, Autonomy for Arab Education in Israel. Rights and Possibilities, Knowledge Discovery, 2014 Spring, 5.

${ }^{99}$ M. Abu-Nimer, Education for Coexistence in Israel: Potential and Challenges, [in:] Reconciliation, Justice, and Coexistence: Theory and Practice, Ed. M. Abu-Nimer, Lanham - Maryland 2001, p. 235-254.

${ }^{100}$ K. Abu Asba, Arab Education in Israel: Dilemmas of a National Minority, Florsheimer Institute, Jerusalem 2005; M. Al-Haj, Education among the Arabs in Israel: Control and Social Change, Jerusalem 1996.

${ }_{101}$ M. Al-Haj, Education among the Arabs in Israel.

102 I. Saban, The Collective Rights of the Palestinian Arab Minority, p. 241-319. 
The comprehensive objectives of the educational system obligate the Arab students to learn about Jewish culture and values. The outcome is clearly apparent in the state curriculum for the elementary and secondary schools: the Arab students are required to study many hours on Jewish culture and history and Hebrew language, more than on the Arab literature and history. In addition, they are required to develop identification with Jewish values and to promote the Zionist aspirations at the expense of the development of national awareness of their own and sense of belonging to their people. The Arab national identity receives far less emphasis, and the Palestinian identity does not have any type of recognition. Nevertheless, the main goal of Jewish studies in the Arab educational system is not to develop cultural competence in Jewish Israeli society but to force the Arabs to understand and like Jewish and Zionist goals and to blur their national identity in Israel. Hence, it is possible to conclude that the economic and specific goals of the curriculum developed for Arab education tend to blur and confuse, and not to strengthen, the creation of Arab identity. ${ }^{103}$

In terms of the learning contents, the researchers of Arab education showed that there have been changes in the educational policy for the Arab population, but these changes are influenced by the thought that the goal is to promote the goals of the political regime in Israel, primarily in all that pertains to their Palestinian identity and to the loyalty of the Arab citizens to the State. The Arab educational system did not recognize the Palestinian identity of the Arab citizens and did not cultivate their being a national minority. In contrast, it aspires to cultivate an alternative identity disconnected from their historical, cultural, and national past.104

\section{Emptying of Contents for the Formation of the Palestinian National Identity in Arab Education in Israel}

The importance of the school for the student in the Arab sector increases because of the lack of informal frameworks and institutions in Arab society. Thus, in relative terms the Arab student spends considerable time in the school, which in turn influences the perception of his identity, attitudes, and outlook. 105

The contents of the curriculum in the Arab schools deny the Palestinian Arab identity and culture and emphasize the Zionist Jewish values, which

${ }^{103}$ M. Al-Haj, Education, Empowerment, and Control; S. Mari, Arab Education in Israel.

104 M. Al-Haj, Arab Educational System in Israel: Issues and Trends, Jerusalem 1994.

105 N. Hatav, The Future Orientation of Youths in Arab Society in Israel: Characteristics and Factors, M.A. Thesis, Jerusalem 1988. 
reinforces naturally the sense of deprivation of the Arab students and teachers and causes steadily increasing alienation. ${ }^{106}$ Mari ${ }^{107}$ maintained that "the Arab educational system aspires to shape the unique Israeli Arab, which is disconnected from the original national and cultural roots, related in an inextricable relationship to the Arab world and the Palestinian world". According to Al-Haj, ${ }^{108}$ the contents of the Arab educational system were intended to create a submissive Arab who is willing to accept his inferiority versus Jewish supremacy and to weaken the Palestinian Arab identity.

In essence, the curriculum and the organizational structure of the Arab educational system in Israel assume barriers for the shaping of the national identity of the student. ${ }^{109}$ In contrast to its Jewish parallel, Arab education does not have educational goals for the development of the national, cultural, or religious belonging or identity. ${ }^{110}$

The development of Arab education in the dominant Jewish culture is subject to conflicting messages. Formal education constitutes for the Arab students a confusing experience since the cultural and language contents conveyed in the schools contradict with the values of the culture and national Arab identity, which they receive in frameworks outside of the school and with which they may identify more.111

Therefore, the issue of autonomy for Arab education challenges the hegemony of the majority group in Israel.112 Therefore, the collective Palestinian Arab educational interests is nearly completely ignored in the language of the State Education Law (Jabareen, 2006), the lack of resources, and the absence of the ability of real influence (Saban, 2002). This policy of the Israeli educational system regarding the Arab education led to the development of alternative national education in the Arab public.

${ }^{106}$ K. Abu-Asba, The School Principal is Subject to Great Pressures on the Part of the Clans, Another Country 2004; D. Golan-Agnon, Why Are the Arab Students in Israel Discriminated Against? [in:] Inequality in Education, Ed. D. Golan-Agnon, Tel Aviv 2004.

107 S. Mari, Arab Education in Israel.

108 M. Al-Haj, Education among the Arabs in Israel.

${ }^{109}$ K. Abu-Asba, Attitudes of Different Factors in Arab Society on the Question of an Alternative Structure for the Arab Educational System in Israel: Summative Report. Israel: Follow-up af-ter Issues of Arab Education in Israel, Gat: Masser 2003.

${ }^{110}$ H. Pinson, D. Anon (Eds.), Citizenship, Civil Society, and Education: The Israeli Case in the Mirror of Western Democracies, [in:] The Language of the Citizen in Israel, Jerusalem 2006.

111 B. Kimerling, Y.S. Migdal, Palestinians: A Nation in Formation, Jerusalem 1991.

112 J. Bruner, Y. Peled, On Autonomy, Abilities, and Democracy: Criticism of Multiculturalism on Liberalism, [in:] Multiculturalism in a Democratic and Jewish State Mounter, Eds. M. Sagi, A. Shamir, Tel Aviv 1998, p. 107-131; J. Rawls, A Theory of Justice, Cambridge 1971. 


\section{Conclusion}

The Arab minority in Israel has the full right to require collective right to education, since it is a native, national, cultural, religious, and lingual minority that has suffered and is still suffering from discrimination and deprivation on a collective basis. ${ }^{113}$

Examination of the educational hierarchy, the teaching workforce, and the curriculum in the Jewish educational system reveals a clear preference for European-Western culture over non-Western Jewish culture, North Africa and Middle Eastern. Largely, it also tends to ignore or to be satisfied with the most minimal exposure to the Arabic language, history, and culture, and it addresses them, even if not in a declared manner, in a negative way. ${ }^{114}$

Arab education thus is a victim of Israeli pluralism not only in that it is managed and controlled by the majority but also in that it is managed by the Jewish majority and the authorities determine the curricula, without the involvement of many Arabs, if any. The involvement of Arabs does not go beyond the limits of the writing or translation of books and study materials according to the painstakingly defined guidelines and does not pass the boundary of the actualization of the policy of the majority. ${ }^{115}$ The authorities of the Arab local governments and the school principals are thus purely technical, while the essential decisions are made in the Ministry of Education. 116

The educational system in Israel has never been perceived as a whole structure in which the Palestinian Arab factor constitutes a legitimate element. Although Israeli society is a pluralistic society, Israel intentionally has not created a common basis for true multicultural education and in the meantime has missed an opportunity of exposing Jewish students to Arab culture. ${ }^{117}$

113 Abas, 2004, in: Education on Hold; Government Policy and Civil Initiatives for the Promotion of Arab Education in Israel.

114 I. Abu-Saad, Multicultural Education and the Palestinian Arab Minority in Israel: The Issue of Bedouin Arab Education in the Negev, [in:] Education in a Multicultural Society: Pluralism and Points of Encounter between Social Rifts, Ed. P. Pery, Jerusalem 2007, p. 125-142.

115 S. Mari, Arab Education in Israel.

116 D. Golan-Agnon, Why Are the Arab Students in Israel Discriminated Against?.

117 I. Abu-Saad, Multicultural Education and the Palestinian Arab Minority in Israel, p. 125-142. 


\section{BIBLIOGRAPHY}

Abu Asba K., Attitudes of Different Factors in Arab Society on the Question of an Alternative Structure for the Arab Educational System in Israel: Summative Report. Israel: Follow-up after Issues of Arab Education in Israel, Institute for Research, Planning, and Educational Counseling, Gat: Masser 2003. (Hebrew)

Abu Asba K., The School Principal is Subject to Great Pressures on the Part of the Clans, Another Country 2004. (Hebrew)

Abu Asba K., Arab Education in Israel: Dilemmas of a National Minority, Florsheimer Institute, Jerusalem 2005. (Hebrew)

Abu Asba K., The Status and Level of Operations of the Arab Educational System in Israel, 2007. (Hebrew)

Abu Ria A., To Be an Arab Citizen in Israel: Characteristics, Challenges, and Obstacles, 2004. (Hebrew)

Abu-Saad I., Multicultural Education and the Palestinian Arab Minority in Israel: The Issue of Bedouin Arab Education in the Negev, [in:] Education in a Multicultural Society: Pluralism and Points of Encounter between Social Rifts, Ed. P. Pery, Carmel, Jerusalem 2007. (Hebrew)

Abu Shindi I., Educational Coping with the Arab-Jewish and Social-Economic Schism, Multidisciplinary Thoughts in Humanistic Education, 2010, 5. (Hebrew)

Abu-Nimer M., Education for Coexistence in Israel: Potential and Challenges, [in:] Reconciliation, Justice, and Coexistence: Theory and Practice, Ed. M. Abu-Nimer, Lexington Books, Lanham - Maryland 2001.

Agbaria A.K., Arab Civil Society and Education in Israel: The Arab Pedagogical Council as a Contentious Performance to Achieve National Recognition, Race, Ethnicity, and Education, 2013.

Agbaria A.K., Introduction: The Policy of Training of Arab Teachers in Israel - The Demand for National and Pedagogical Uniqueness, [in:] Training Teachers in Palestinian Society in Israel - Institutional Practices and Educational Policy, Ed. A.K. Agbaria, Resling 2013. (Hebrew)

Agbaria A.K., Jabareen Y., Policy of Training Arab Teachers in Israel in the Mirror of the Right to Education: Issues of Governance as an Expression of Recognition of the National-Cultural Uniqueness, Journal for Study and Research in Education, 2015. (Hebrew)

Agbaria A.K., Mahjana I., Arab Education in Israel, between the Discourse of Achievement and the Discourse of Recognition, Two Thousand: Multidisciplinary Journal for Review, Philosophy, and Literature, 2009, 34. (Hebrew)

Al-Haj M., The Situation of the Arab Education. Identity, Coexistence and Contents of Education, The National Committee of Chairmen of Arab Local Authorities and the Follow Up Committee for Arab Education, 1988, 1. (Arabic)

Al-Haj M., Trouble of Employment among Arab Academics in Israel, [in:] Arab Academics in Israel: Main Characteristics, Potential of Graduates, and Situation, Ed. M. Al-Haj, The Jewish-Arab Center, Haifa University, Haifa 1988. (Hebrew)

Al-Haj M., The Political Organization of the Arab Population in Israel, The Development of a Center in the Margins, 1992. (Hebrew)

Al-Haj M., Arab Educational System in Israel: Issues and Trends, Floresheimer Institute for Policy Researches, Jerusalem 1994. (Hebrew)

Al-Haj M., Education, Empowerment, and Control: The Case of the Arabs in Israel, State University of New York Press, Albany, New York 1995. 
Al-Haj M., Kinship and Modernization in Developing Societies: The Emergence of Instrumentalized Kinships, Journal of Comparative Family Studies, 1995 October, 26(3).

Al-Haj M., Education among the Arabs in Israel: Control and Social Change, Magnes Press, Jerusalem 1996. (Hebrew)

Al-Haj M., Higher Education among the Arabs in Israel: Situation, Problems, and Trends, Haifa University, Haifa 2001. (Hebrew)

Amara M., Saban I., The Status of the Arabic Language in Israel: Law, Reality, and Boundaries of Use in Law to Change the Reality, State and Society, 2004, 4. (Hebrew)

Arian A., Ben-Nun P., Barnea S., The Measure of Israeli Democracy, Adults and Youths, 2004. (Hebrew)

Avnon D., The Non-Democratic Aspect of the Basic Laws on the Topics of the Rights of Man, Politics, 1998, 2. (Hebrew)

Barak A., The Values of the State of Israel as a Jewish and Democratic State, Multidisciplinary Thinking in Humanistic Education, 2011, 6. (Hebrew)

Bargouti S., Israeli Educational Core Requires Fair Inclusion of the Arab Public, Multidisciplinary Thought in Humanistic Education, 2011, 6. (Hebrew)

Boymel Y., Principles of the Policy of Discrimination towards the Arabs in Israel, 1948-1968, The New East, 2002.

Brenner M., Frisch S., Zionism: A Brief History, Markus Wiener Publishers, 2003.

Bruner J., Peled Y., On Autonomy, Abilities, and Democracy: Criticism of Multiculturalism on Liberalism, [in:] Multiculturalism in a Democratic and Jewish State Mounter, Eds. M. Sagi, A. Shamir, Ramot, Tel Aviv 1998. (Hebrew)

Cohen, 1980, in: I. Zalkovitz, In the Search for Identity: Islam, Nationalism, and Armed Struggle in the Fatah Movement, 1959-1968, [in:] The New East, Eds. B. Araki Kolerman, M. Hatina, The Open University, 2008. (Hebrew)

Dahan Y., Companionship? Depends for Whom? The Sting, 2010 November 16, Retrieved on April 30, 2012 from: www.haokets.org/2010/11/16 שקל-אלף-35-תמורת-מנהיג (Hebrew)

Donyets Kedar, 2012, in: H. Gavarin, The Nakba, Law, and Loyalty: The Hobbesian Moment of the Palestinians in Israel, Theory and Criticism: An Israeli Stage, 2014 Spring, 42. (Hebrew)

Dovrat Report, 2005

החינוך משרד - לחינוך הלאומית התוכנית

http:/ / www.tandfonline.com/doi/pdf/10.1080/13537120701706021

Dror Y., Interconnected Vessels in National Education: The Zionist Story, Magnes Press, Jerusalem 2007. (Hebrew)

Eisenstadt, 1989, in: A. Ghanem, M. Levin-Rosales, Game of Identities: The Construction of Identity among Palestinian Women Citizens of Israel Who Studied in Schools in the Jewish Sector, Trends, 2015 May, 51. (Hebrew)

Feldman E., Ethnicity, Politics, and Education - The First Decade of Independent Education, 1953-1963, From Generation to Generation, 2007, 31. (Hebrew)

Gabizon R., Balfour N., Between Demand for Liberty and Autonomy of Arab Education in Israel: Rights and Possibilities, 2005. (Hebrew)

Ghanem A., Mustafa M., The Palestinians in Israel - The Policy of the Minority in the Ethnic State, Medar - The Palestinian Center for the Study of Israeliness, 2009. (Arabic)

Gilat I., To Be Close: First Aid for the Teacher in Coping with the Students' Troubles, Keter, Tel Aviv 2007. (Hebrew)

Golan-Agnon D., Why Are the Arab Students in Israel Discriminated Against? [in:] Inequality in Education, Ed. D. Golan-Agnon, Babel, Tel Aviv 2004. (Hebrew) 
Gross Z., State Religious Education in Israel: Between Tradition and Modernity, [in:] Education as a Social Challenge, Eds. Z. Gross, Y. Dror, Collection of Articles on State Religious Education and on Informal Education in Memory of Professor Moti Bar-Lev, Tel Aviv University, Tel Aviv 2004. (Hebrew)

Hamisi R., Strategies of Settlement in the Occupied Territories and Implication on the Main Planning and Development in Palestine, Journal for the Research of Palestinianism, 1998 Winter, 10(37). (Arabic)

Hatav N., The Future Orientation of Youths in Arab Society in Israel: Characteristics and Factors, M.A. Thesis, The Open University, Jerusalem 1988. (Hebrew)

Ichilov O., Establishment of Public Education in Israel and Retreat from It, [in:] Privatization and Commerce in Public Education in Israel, Ed. O. Ichilov, Ramot, Tel Aviv 2010. (Hebrew)

Israel Ministry of Foreign Affairs, Zionist Leaders: David Ben-Gurion 1886-1973, Israel Ministry of Foreign Affairs Website, Retrieved 13 July 2011.

Israel Ministry of Foreign Affairs (n.d.) Declaration of Establishment of State of Israel, Israel Ministry of Foreign Affairs Website, 14 May 1948, Retrieved 8 April 2012.

Jabareen Y., Law and Education: Critical Perspectives on Arab Education in Israel, American Behavioral Scientist, 2006, 49(8).

Jabareen Y., On the Constitutional Status of the Arab Minority in Israel: New Motion, State and Society, 2010, 7(1). (Hebrew)

Jabareen Y., Critical Perspectives on Law, Equal Citizenship and Transformation, [in:] Plurality and Citizenship in Israel, Ed. D. Ivanov, 2012, 68.

Jabareen Y., Agbaria A.K., Education on Hold; Government Policy and Civil Initiatives for the Promotion of Arab Education in Israel, Haifa University, The Faculty of Law, The Clinic for the Rights of the Palestinian Arab Minority, Drasat: Arab Center for Law and Policy, 2010. (Hebrew)

Jabareen Y., Agbaria A., Autonomy for Arab Education in Israel. Rights and Possibilities, Knowledge Discovery, 2014 Spring, 5. (Hebrew)

Jamal A., Liberal Zionism: Judgmental Enlightenment and the Challenge of Multiculturalism in Israel, State and Society, 2004, 4. (Hebrew)

Jamal A., On the Patterns of the Establishment of the National Inequality in Israel, 2004. (Hebrew)

Jamal A., Citizenship Lexicon for Arab Schools in Israel, Gilo Center for Civic Education and Democracy, Jerusalem 2005.

Jamal A., Struggle over Time and the Power of Temporariness: Jews and Palestinians in the Maze of History, [in:] Men in the Sun, Eds. H. Perach, T. Ben Tzi, Herzeliya: Museum, 2009. (Hebrew)

Kalai H., The End of the Race is Determined by the Beginning Thought, Journal of the Law Bar in Israel, 2014, 23. (Hebrew)

Kalai H., The Freedom of Thought and the Freedom Not to Think: Theoretical Aspects of the Right to Freedom and the Right to Education, Opinion: Multidisciplinary Journal for Education, Society, and Culture, 2014, 6, Fall. (Hebrew)

Katz Y. (Ed.), Towards an Educational Revolution, Following the Van Lear Conference for Education on the Implementation of the Dovrat, Report, 2006. (Hebrew)

Kimerling B., Migdal Y.S., Palestinians: A Nation in Formation, Keter Press, Jerusalem 1991. (Hebrew)

Koren H., The Identity as Awareness: The Palestinians and the Arab Citizens of Israel - Between Unity and Uniqueness, National Security, 2009 August, 7. (Hebrew) 
Lautman D., Education as the True Way to Close Gaps and Promote Society, Multidisciplinary Thought in Humanistic Education, 2009, 4. (Hebrew)

Lisk, 1990:

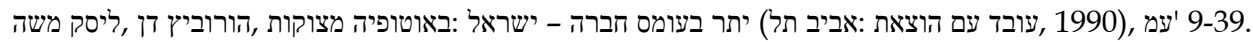

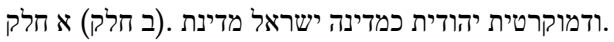

Lustick I., Arabs in the Jewish State: Israel's Control of a National Minority, University of Texas Press, Austin, Texas 1980.

Mahajana I., The Declared Policy in the Training of the Arab Teachers in Israel to Cope with Students in Distress and in Crisis, [in:] The Training of Teachers in Palestinian Society in Israel, Ed. A. Agbaria, Ressling 2013. (Hebrew)

Mari S., Arab Education in Israel, Syracuse University Press, Syracuse - New York - Boulder 1978.

Markman, Yonah, 2010

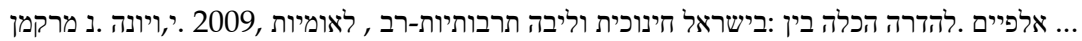

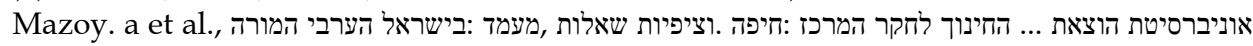
1995.

Mazoy. a et al., 2002:

מ :בתוך ,"בחינוך הפמיניסטי המחקר :מבוא" ... - ... 27-952 פורמאלי והבלתי הפורמאלי בחינוך מגדריים היבטים הספר-ובית הוראה כוח ,מיגדר :בישראל הערבי החינוך .2002 .אנדרה ,מזאוי .... .(עורכות) פרי .ופ צלרמאיר כשדה צורה

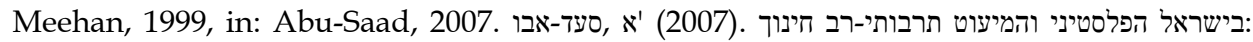
'עמ ,כרמל :חיפה ,תרבויות מרובת בחברה חינוך .(עורכת) פרי 'פ :בתוך .בנגב בדואי-הערבי החינוך סוגיית p. 142-125.

Morris B., Victimization, Am Oved 2003. (Hebrew)

National Task Force for the Advancement of Education in Israel, 2005.

Noyberger B., Minorities and Democracy, [in:] Knowledge, Society, and Regime, Ministry of Education, Culture, and Sport, Center for Explanation/Service of Publications, Old City Press, Jerusalem 1995. (Hebrew)

Oron Y., Israeli Identities: Jews and Arabs opposite the Mirror and the Other, Education and Its Environment, 2010, 32. (Hebrew)

Oron Y., Between Jewishness and Israeliness. Relation of Jewish Students in Israel to Nation, State, Land, and Religion. Identities in Formation in Israeli Culture, The Open University, UK 2013. (Hebrew)

Ozacky-Lazar S., The Military Government as a Mechanism of the Control of the Arab Citizens, 1948-1958, A New East, 2012, 43. (Hebrew)

Pinson H., Anon D. (Eds.), Citizenship, Civil Society, and Education: The Israeli Case in the Mirror of Western Democracies, [in:] The Language of the Citizen in Israel, The Hebrew University of Jerusalem, Jerusalem 2006. (Hebrew)

Piron S., Educational Core: On the Importance of the Cultural Individual, Personal Development, and the Scholastic Level, Multidisciplinary Thinking in Humanistic Education, 2011, 6. (Hebrew)

חוברת ,ישראל :מתוך .בישראל חדש שמאל של הייחודי המקרה :חדש ישראלי שמאל תנועת פורטוגז עדי, Portogez 21. חזן מאיר :עריכת .2013 אביב פוריב

Rabin Y., The Right to Education, Li-On Sarigim, Nebo 2002. (Hebrew)

Rawls J., A Theory of Justice, Harvard University Press, Cambridge 1971.

Rom A., The Process of the Development of Curricula in Five Chosen Countries, Ministry of Education, Jerusalem 2009. (Hebrew) 
Rottenberg N., Shared Educational Core for the Children of Israel: Obstacles and Overcoming Them, [in:] Towards an Educational Revolution, Ed. D. Inbar, Van Lear Institute, 2006, p. 214-227. (Hebrew)

Saar A., Koya: On Strong Women in Palestinian Society in Israel, [in:] Generations, Spaces, Identities: Contemporary Looks on Society and Culture in Israel, Eds. H. Herzog, T. Kochavi, S. Zelniker, Tel Aviv University, Tel Aviv 2007. (Hebrew)

Saban I., The Collective Rights of the Palestinian Arab Minority: What There Is, What There Isn't, and the Taboo, Studies in Law, 2002, 26, 1. (Hebrew)

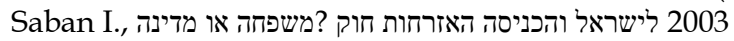

Sheferman K.T., Arab Identity in a Jewish and Democratic State, Parliament: Portrait of the Israeli Public, 2008 April, 58. (Hebrew)

Shenhar Committee Report, 2012. Coeditor, Comparative Education Review [USA] (20092012). International .... the Shenhar Committee Report in State Junior High Schools'

Shwade U., Shavit Y., Integration of Jews and Arabs in the Schools in Israel, Taub Center for the Research of Social Policy in Israel, 2014. (Hebrew)

Smooha S., Arabs and Jews in Israel, 1989, 1, WestView Press.

Smooha S., The Viability of Ethnic Democracy as a Mode of Conflict-Management: Comparing Israel and Northern Ireland, Comparing Jewish Societies, 1997.

Smooha S., Measures of Jewish-Arab Relations in Israel, Haifa University, Haifa 2004. (Hebrew)

Stendel O., Arabs of Israel: Between Hammer and Anvil, Academon, 1992. (Hebrew)

Stern Y., Proposal of a Basic Law: Trampling of Minorities, Haaretz, 2012 April, 22. (Hebrew)

Talshir G., Citizenship, Civil Society, and Education: The Israeli Case in the Mirror of Western Democracies, [in:] The Language of the Citizen in Israel, Eds. G. Talshir, D. Anon, The Hebrew University of Jerusalem, Jerusalem 2006. (Hebrew)

Tomasevski K., Globalizing What: Education as a Human Right or as a Traded Service? Indiana Journal of Global Legal Studies, 2004, 12(1).

Tzartzur S., Arab Education: A Picture of the Situation and a Look to the Future, [in:] Jubilee for the Educational Systems in Israel, Ed. E. Peled, Ministry of Education, Culture, and Sport, Ministry of Defense, Jerusalem 1999. (Hebrew)

Yiftachel O., Stateless Citizenship: The Palestinian-Arab Citizens of Israel, 2002.

Yonah Y., Goodman Y., Mix of Identities: Critical Discussion of Religiosity and Secularism in Israel, Van Lear Institute, HaKibbutz HaMeuchad Press, 2004. (Hebrew)

Zadja J., Daun H., Saha L.J. (Eds.), Nation-Building, Identity and Citizenship Education, Cross Cultural Perspectives, 2009.

Zilbersheid U., The Legal-Political Development of the Declaration of Independence - Victory of the Perception of Bourgeoisie Democracy, Democratic Culture, 2009, 12, 7. (Hebrew)

Zimran I., There Is Another Way - Self-Education of Teachers for Meaningful and ValueOriented Teaching, [in:] Values and Education for Values: Issues in Teacher In-service Training, Ed. M. Bar-Lev, The Hebrew University, Jerusalem 1999. (Hebrew)

Zisnavin D., The Jewish Educational System in Israel from the Days of the Initial Settlement until Today, [in:] Changes in Education, Eds. Dror, Nevo, Shapira, The Open University, UK 2011. (Hebrew) 